\title{
Vietnam's financial turmoil: What's and Why's
}

\author{
Vietnamica \\ Stratfor Worldview \\ Stratfor WORLDVIEW $^{\text {w }}$
}

May 22, 2013

https:// worldview.stratfor.com/article/ vietnams-financial-turmoil-whatsand-whys 


\section{Vietnam's financial turmoil: What's and Why's}

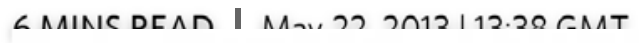

\section{WWW.VIETNAMICA.NET \\ Q Quality Insights on Vietnam's Economy and Business \\ Financially and Time-Saving Tool For Your Making Well Informed Decisio}

Originally published on Vietnamica

The emerging market economy of Vietnam, a $\$ 135$ billion economy with 90 million people, has been undergoing a major crisis - output growth has declined to the lowest point in many years, liquidity crunch problems have worsened, and bankruptcy and unemployment statistics have continued rising (see also Vuong, 2012).[1] With an insecure and vulnerable transition 
economy, this crisis has led to financial failures among the business community. (Vuong, 2010).[ii] Understanding the crisis and its key dimensions is crucial to not only businesspeople and investors but also policy makers and researchers.

Vuong, Napier, and Tran (2013)[iii] employ categorical data analysis to examine 256 cases of financial failure and fraud in Vietnam's chaotic years from 2007 to 2013, following a flourishing post-Doi Moi (i.e., market renovation period) when Vietnam was depicted as one of the world's fastest-growing economies. They suggest that a rent-seeking approach, or resource-based orientation, alone does not help foresee outcomes of business intentions while the association between orientation (on resources vs. market prospects) and approach (rent-seeking vs. creative performance/innovation) is the best-fit predictor.

As Vietnamese became familiar with concepts of investments, they hoped for returns that were good enough to compensate their increasing risk appetite. The types of assets and investments available also grew in scope. A typical household (or individual) considers five types of assets, namely gold, foreign currencies, interest-bearing bank deposits, land and housing, and stocks. Their willingness for pursuing these assets is given in Table 1.

Table 1 - Typical Vietnamese households' preferable investments

\begin{tabular}{|l|l|l|}
\hline & Response & Percentage \\
\hline Gold & 3052 & 28.3 \\
\hline $\begin{array}{l}\text { Foreign currencies } \\
\text { (mostly US Dollars) }\end{array}$ & 1297 & 12.0 \\
\hline Bank deposits & 3250 & 30.1 \\
\hline
\end{tabular}




\begin{tabular}{|l|l|l|}
\hline Land/housing & 2661 & 24.7 \\
\hline Stocks & 520 & 4.8 \\
\hline Source: Data from an online survey by \\
VNExpress.net; the total number of responses is \\
10,780. (Accessed May 10, 2013).
\end{tabular}

However, as the economy has grown and changed from a planned to a more market oriented economy, many individuals and households sought, and ultimately demanded, much higher financial payoffs. As a result, they were willing to tolerate much higher risks involved in their transactions and thus pursued different investment vehicles than what had previously been common. Unfortunately, most of these approaches were in the socalled underground economy. The result: many of such casual investors seeking a sort of El Dorado - the City of Gold - had intended to act as "sharks" and make money, but in fact became "shark food" when they encountered unfavorable economic conditions (Vuong, 2011).[iv] Many of them became victims of financial failure or fraud at the hands of people they had trusted to bring them satisfactory returns. The situation becomes more critical when the economy is ill, with bad debts rising, and the symbols of prosperity - the stock and real estate market degenerating into turmoil. It appears that many households and ‘quasi-entrepreneurs' acted as rent-seekers. In essence, they attempted to tap a growing base of resources, capital and physical, to enter into non-creative activities that did not add value to their operations, as they simply tried to create 'money machines.'

Financial ratios and technical calculations are popular in 
predicting financial collapse. However, the predictors face the challenges of availability of data, professional knowledge, and perhaps, the most important, the performance of an existing financing scheme. Vuong et al. (2013) suggests there are intuitive and cognitive indications that could help predict ex-ante outcomes.

Orientation and approach of a business' intention, which are statistically interdependent, help explain the increasing number of financial collapses during economic turmoil. When business prospects are negative, an attempt to raise funds derived from the availability of financial resources and lack of innovation signals is highly likely to be fraudulent. The existence of innovation does not ensure a successful business but improves creditors/investors' confidence in the entrepreneurial endeavors of fundraisers. Indeed, a neglect of creative performance and reliance on capital and physical resources may lead a business to experience acute problems caused by the law of diminishing returns (Vuong and Napier 2013). [v]

Psychology and the resulting decisions-by greed and scarce business opportunities-may also induce creditors/investors to put their money in risky investments (Pressman 1998).[vi] It is not because of asymmetric information but because of the lack of costbenefit consideration and careful multi-layer filtering of information (e.g., Vuong and Napier, 2012)[vii] where investors fall prey to the dangers lurking in conditions of turmoil. Despite an appreciation of the credit crunch and economic stagflation, many investors still scramble to withdraw their savings, gather cash from family members and friends, and even to mortgage their 
houses to lend money and then hope for pretty profits. They innocently ignore the fact that they lent money at sky-high interest rates and that none was able to repay a loan at such rates plus a premium of the usury lenders.

Last but not least, it appears that over-tapping available resources and strictly seeking profits to the detriment of investing within the firm in more innovative directions may likely result in collapse. An economic setting of an easing monetary policy and worsening business prospects - for instance, lowered interest rates in association with increasing unemployment -is a comfortable environment for financial frauds blossom. In light of this, the economy has to pay for the increasing cost of funds while society's trust is eroded. Fortunately, entrepreneurship development shifting business orientations to encompass innovation capacity building and creativity - can pave a pathway out of this deadlocked situation.

[i] Vuong, Q.H. (2012). "Vietnam's Economic Challenges," Stratfor Global Intelligence. <http://www.stratfor.com/other-voices /vietnams-economic-challenges>, August 21.

[ii] Vuong, Q.H. (2010). Financial markets in Vietnam's transition economy: Facts, insights, implications. Saarbruken, Germany: VDM Verlag.

[iii] Vuong, Q.H., N.K. Napier, and T.D. Tran (2013). "Rentseekers' lost El Dorado: Vietnam's financial turmoil, 2007-2013," CEB Working Paper, No. 13-020, Solvay Brussels School of Economics \& Management, Université Libre de Bruxelles, May 17 [iv] Vuong, Q.H. (2011, July 6).Vietnam's underground economy: 
Where "sharks" were food. Stratfor Global Intelligence.

$<$ http://www.stratfor.com/other-voices/vietnams-underground-

economy-where-sharks-were-food>

[v] Vuong, Q.H., and N.K. Napier (2013). Resource curse or destructive creation in transition turmoil. China-USA Business Review, 12(5), 486-493.

[vi] Pressman, S. (1998). On financial frauds and their cause. American Journal of Economics and Sociology, 57(4), 405-421.

[vii] Vuong, Q.H., and N.K. Napier (2012). Coffee Filters and Creativity: The Value of Multiple Filters in the Creative Process, CEB-ULB Working Paper Series, WP No 12-036, Solvay Brussels School of Economics and Management, Université Libre de Bruxelles.

\section{Subscribe to Intelligence Over News}

Independent Strategic Analysis | Objective Geopolitical Insights

Start your subscription today!

Article Search

\# 
https://worldview.stratfor.com/article/vietnams-financial-turmoil-whats-and-whys

In the Eurozone, 2021 Portends

More Stimulus -- and More Debt

\begin{tabular}{|c|c|}
\hline $\begin{array}{l}\text { of a Heartland } \\
\text { Could Upset } \\
\text { America's } \\
\text { Balance }\end{array}$ & $\begin{array}{l}\text { 'Trump's Re- } \\
\text { Election Would } \\
\text { Translate to } \\
\text { Tariffs }\end{array}$ \\
\hline
\end{tabular}

Copyright (c) Stratfor Enterprises, LLC. All rights reserved. 


\section{References}

[1] Vuong, Q.H. (2012). Vietnam's Economic Challenges. Stratfor Global Intelligence (August 21). <http:/ / www.stratfor.com/ othervoices/vietnams-economic-challenges>.

[2] Vuong, Q.H. (2010). Financial markets in Vietnam's transition economy: Facts, insights, implications. Saarbruken, Germany: VDM Verlag.

[3] Vuong, Q.H., Napier, N.K., \& Tran, T.D. (2013). Rent-seekers' lost El Dorado: Vietnam's financial turmoil, 2007-2013. CEB Working Paper, No. 13-020, Solvay Brussels School of Economics \& Management, Université Libre de Bruxelles, May 17

[4] Vuong, Q.H. (2011). Vietnam's underground economy: Where "sharks" were food. Stratfor. <http:// www.stratfor.com/ othervoices/vietnams-underground-economy-where-sharks-were-food>

[5] Vuong, Q.H., \&Napier, N.K. (2014). Resource curse or destructive creation in transition. Management Research Review, 37(7), 642-657.

[6] Pressman, S. (1998). On financial frauds and their cause. American J ournal of Economics and Sociology, 57(4), 405-421.

[7] Vuong, Q.H., \&Napier, N.K. (2014). Making creativity: the value of multiple filters in the innovation process. International J ournal of Transitions and Innovation Systems, 3(4), 294-327. 